\title{
An assessment of exposure to glutaraldehyde in hospitals: typical exposure levels and recommended control measures
}

\author{
P Leinster, J M Baum, P J Baxter
}

\begin{abstract}
An assessment of exposure to glutaraldehyde in cold sterilisation and $x$ ray development processes was undertaken in 14 locations at six hospitals in south east England. The results obtained indicate that routine exposures of hospital workers to airborne concentrations of the compound are within the current United Kingdom occupational exposure limit of $0.7 \mathrm{mg} \mathrm{m}^{-3}$. There was the potential for skin contact in many of the activities observed and alternative sterilisation and disinfection procedures would have been more appropriate in some situations. Recommendations are made on reducing exposures as the current occupational exposure limit for this compound may not be appropriate.
\end{abstract}

\section{(British Fournal of Industrial Medicine 1993;50:107-111)}

Glutaraldehyde is widely used in hospitals as a cold sterilising and disinfecting solution, in particular for endoscopes and other delicate instruments that may be damaged by hypochlorite solution, the only other agent currently recommended for its effectiveness against HIV. It is also present as a hardening agent for emulsions in certain $x$ ray developing solutions. Some glutaraldehyde is liberated when $x$ ray films are developed.

The United Kingdom Health and Safety Executive's National Interest Group for the Health Service has identified glutaraldehyde as a substance that should be given particular consideration when making assessments under the Control of Substances Hazardous to Health (COSHH) Regulations $1988^{1}$ within hospitals. The reason given for highlighting glutaraldehyde was a steadily

Thomson-MTS Ltd, The Stocks, Cosgrove, Milton Keynes MK19 7JD

P Leinster, J M Baum

University of Cambridge Clinical School, Addenbrooke's Hospital, Cambridge CB2 $2 Q Q$

P J Baxter increasing number of reports of health problems from users, including skin and respiratory sensitisation and irritant effects. Whereas sensitisation does not seem to be common it is important because affected subjects may have to be transferred to work that does not involve a risk of exposure to glutaraldehyde.

The objectives of the study reported in this paper were to assess personal exposures during the use of glutaraldehyde in cold sterilising and in $x$ ray development processes and to provide advice on appropriate control measures.

Glutaraldehyde is a volatile substance and under certain circumstances significant airborne concentrations may be generated at room temperature. The vapours are irritating to the skin, eyes, nose, and lungs, an effect enhanced when the material is "activated" by the addition of sodium bicarbonate, as occurs, for example, with cold sterilising solutions. Corrado et $a^{2}$ presented four case studies of endoscopy nurses complaining of respiratory symptoms due to glutaraldehyde, of which two had positive provocation tests. Norback ${ }^{3}$ surveyed the prevalence of skin and respiratory symptoms in hospital workers exposed to glutaraldehyde and compared these with a non-exposed control group. A significantly increased rate of skin and respiratory symptoms and headaches was found in the exposed group. For personnel using manual procedures the 15 minute time weighted average (TWA) exposures were in the range $<0.01-0.57 \mathrm{mg} \mathrm{m}^{-3}$. For personnel using automatic sterilisers the 15 minute TWA exposures were in the range $0.01-0.18$ $\mathrm{mg} \mathrm{m}^{-3}$. The results for a well ventilated room (range $0.01-0.03 \mathrm{mg} \mathrm{m}^{-3}$ ) were lower than those from a poorly ventilated room (range 0.13$0.18 \mathrm{mg} \mathrm{m}^{-3}$ ). It is of interest to note that in this study the symptoms that were most significantly associated with glutaraldehyde were skin related. Jachuk et $a l^{4}$ reported eight cases of discomfort including watering eyes, rhinitis, breathlessness, and dermatitis in endoscopy staff exposed to glutaraldehyde. Samples were collected in bubblers containing 3-methyl-2-benzothiazolinone hydrazone hydrochloride (MBTH) and it should be 
noted that the sampling procedure used will respond to any airborne aldehyde present and is not specific for glutaraldehyde. A 60 minute TWA exposure of $0.42 \mathrm{mg} \mathrm{m}^{-3}$ was reported. Wiggins et $a l^{5}$ described a case of recurrent nose bleed, together with other symptoms of upper respiratory tract irritation and also a skin rash, in a hospital employee who sterilised endoscopes. No exposure data were given but poor ventilation was reported as was the presence of uncovered containers of solution. Activities included the pouring and mixing of solutions. In a publication ${ }^{6}$ concerned with the wiping down of surfaces in an operating theatre, five minute TWA exposures up to $0.11 \mathrm{mg} \mathrm{m}^{-3}$ when a $0.5 \%$ solution was used, and up to $2.0 \mathrm{mg} \mathrm{m}^{-3}$ when a $3.0 \%$ solution was used were reported. Over the duration of the cleaning period the TWA concentrations were 0.04 and $0.53 \mathrm{mg} \mathrm{m}^{-3}$ respectively.

The irritant threshold for glutaraldehyde is reported to be a vapour concentration of 0.8 to $1.0 \mathrm{mg} \mathrm{m}^{-3}$. The odour detection threshold (the airborne concentration at which the vapour can reliably be identified as being glutaraldehyde) is about $0.14 \mathrm{mg} \mathrm{m}^{-3} .^{7}$ It has been found from studies of other materials that this detection threshold is on average three times the concentration at which a smell can be perceived. ${ }^{8}$ This would suggest that glutaraldehyde might be perceived to be present at airborne concentrations of approximately $0.05 \mathrm{mg} \mathrm{m}^{-3}$. The current United Kingdom occupational exposure standard for glutaraldehyde is $0 \cdot 7$ $\mathrm{mg} \mathrm{m}^{-3}$ for a 10 minute TWA. ${ }^{9}$

\section{Uses of glutaraldehyde}

AS A COLD STERILISING SOLUTION

Glutaraldehyde is marketed as a cold sterlising solution under various trade names including CIDEX and ASEP. Typically this is a $2 \%$ solution in water. Before use the liquid is activated by the addition of sodium bicarbonate as a powder. The activated solution is then poured into trays, or tanks in automatic disinfection units, as appropriate. This task is typically completed in three to four minutes. Once activated, the solution has a life span of one to two weeks.

CIDEX was the most common sterilising agent encountered during the study and is used to describe glutaraldehyde solution in the remainder of the report. The most common use of CIDEX during the surveys was for the cold sterilisation of endoscopes. ${ }^{10}$

In its simplest form of use CIDEX is poured into tubs or bowls for the manual cleaning and sterilising of endoscopes. Used in this way there is a potential for splashes on to the skin and for inhalation of glutaraldehyde vapour.

Increasingly, automated units for endoscope dis- infection are being developed by equipment suppliers. These still require the use of CIDEX but decrease the risk of the operators being exposed to glutaraldehyde either by skin contact or by inhalation. The types of automated units encountered during the field work were the Olympus $\mathrm{KC10}$, the Olympus Keymed Auto-Disinfector 2, and the Olympus EW 10 Automatic.

With the Olympus KC10 unit the operator has to tip buckets of CIDEX solution into the cleaning tray. Both the Auto-Disinfector 2 and the EW10 are more automated. The EW 10 unit is the most fully automated. The operator places the endoscope in a cleaning tray, closes the lid, and the machine then automatically runs through a preset cleaning cycle. This unit will not operate with the lid open.

\section{IN THE DEVELOPMENT OF $X$ RAY FILMS}

Glutaraldehyde is a minor component of many $x$ ray developing fluids, typically present in concentrations of a few percent. Direct contact with the developing solutions is only likely to occur when solutions are changed or when parts of the processing equipment are cleaned at the end of the day.

\section{Sampling and analysis}

Seventy seven samples were collected, 39 of which were personal samples, at 14 locations in six hospitals in south east England. Four of these were teaching hospitals and two were non-teaching hospitals. Table 1 shows the individual locations monitored. Each hospital was surveyed over the course of one working day.

The Occupational Health Department in each hospital was asked to identify the areas in which CIDEX was used to try and ensure that all uses of CIDEX were included.

Both personal and static samples were collected in accordance with the procedure detailed in Occupational Safety and Health Method 64. ${ }^{11}$ This involves drawing air through glass fibre filters impregnated with 2,4 dinitrophenyl hydrazine and phosphoric acid. Two filters are loaded in series in the sampling head, the second acting as a backup in case of incomplete absorption by the first. A pump flow rate of $11 \mathrm{~min}^{-1}$ was used; this was checked with a rotameter at the start and end of the sampling period. The contents of the filters were subsequently analysed by high performance liquid chromatography.

Personal exposures were determined from samplers worn by individual workers, with the sampling head located in the breathing zone. Thirty nine personal samples were collected in 13 of the 14 locations investigated. A fully automated EW 10 unit was used in the 14th location and staff did not stay near it while it was operating. Samples were 
Table 1 Description of individual locations monitored

\begin{tabular}{|c|c|c|c|c|c|c|c|}
\hline $\begin{array}{l}\text { Location } \\
\text { No } \\
\end{array}$ & Description & $\begin{array}{l}\text { Approximate } \\
\text { size (m) }\end{array}$ & Cleaning unit & $\begin{array}{l}\text { Mechanical } \\
\text { ventilation }\end{array}$ & $\begin{array}{l}\text { Windows } \\
\text { open }\end{array}$ & $\begin{array}{l}\text { Duration of } \\
\text { session }(h)\end{array}$ & $\begin{array}{l}\text { No of } \\
\text { endoscopes } \\
\text { cleaned }\end{array}$ \\
\hline $\begin{array}{l}1 \\
2 \\
3 \\
4\end{array}$ & $\begin{array}{l}\text { Endoscopy suite } \\
x \text { Ray theatre } \\
\text { Endoscopy unit } \\
\text { Endoscopy room }\end{array}$ & $\begin{array}{l}6 \times 4 \\
2.5 \times 2.5 \\
6 \times 6\end{array}$ & \multirow{2}{*}{$\begin{array}{l}\text { Olympus EW } 10 \\
\text { Olympus Keymed } 2 \\
\text { Olympus Keymed } 2 \\
\text { Manual-2 round bowls } \\
1 \text { trough } 1 \mathrm{~m} \text { long } \\
2 \text { troughs } 1 \mathrm{~m} \text { long } \\
\text { Olympus Keymed } 2 \\
\text { Olympus Keymed } 2\end{array}$} & $\begin{array}{l}\text { No } \\
\text { No } \\
\text { No } \\
\text { One Ventaxia type fan }\end{array}$ & $\begin{array}{l}\text { No } \\
\text { No } \\
\text { No }\end{array}$ & $\begin{array}{r}4 \\
24 \\
4\end{array}$ & $\begin{array}{l}14 \\
10 \\
12\end{array}$ \\
\hline $\begin{array}{l}5 \\
6 \\
7\end{array}$ & $\begin{array}{l}\text { Gastroscopy theatre } \\
x \text { Ray room } \\
\text { Endoscopy room }\end{array}$ & $\begin{array}{l}3 \times 3 \\
6 \times 12 \\
2.4 \times 1.75\end{array}$ & & \multirow{2}{*}{$\begin{array}{l}\text { No } \\
\text { Yes (14 changes/h) } \\
\text { Yes (one general } \\
\text { extract point) } \\
\text { No } \\
\text { No }\end{array}$} & $\begin{array}{l}\text { No } \\
\text { No } \\
\text { No }\end{array}$ & $\begin{array}{l}6-8 \\
3-4 \\
4\end{array}$ & $\begin{array}{l}20-25 \\
4-10 \\
\text { Up to } 18\end{array}$ \\
\hline $\begin{array}{l}8 \\
9\end{array}$ & $\begin{array}{l}\text { Outpatient clinic } \\
\text { Endoscopy clinic }\end{array}$ & $\begin{array}{l}3.1 \times 3.1 \\
2.5 \times 2.4\end{array}$ & \multirow{2}{*}{$\begin{array}{l}\text { Manual_one tank } \\
\text { Manual-2 troughs } \\
1 \mathrm{~m} \text { long } \\
\text { Olympus Keymed } 2\end{array}$} & & $\begin{array}{l}\text { No } \\
\text { No }\end{array}$ & $\begin{array}{l}4 \\
3-4\end{array}$ & $\begin{array}{l}\text { Up to } 16 \\
15\end{array}$ \\
\hline 10 & $\begin{array}{l}\text { Gastroendoscopy } \\
\text { clinic }\end{array}$ & $3.4 \times 5.4$ & & No & No & 4 & Up to 20 \\
\hline $\begin{array}{l}11 \\
12 \\
13\end{array}$ & $\begin{array}{l}\text { Gynaecology theatre } \\
\text { Haemophilia centre } \\
\text { Dark rooms }\end{array}$ & $\begin{array}{l}\frac{6 \times 7}{5 \cdot 9} \times 2 \cdot 2\end{array}$ & $\begin{array}{l}\text { Manual-2 tanks } \\
\text { NA } \\
\text { NA }\end{array}$ & \multirow{2}{*}{$\begin{array}{l}\text { Yes ( } 18.6 \text { changes/h) } \\
\text { No } \\
\text { Yes (air change rate } \\
\text { unknown) } \\
\text { No }\end{array}$} & $\begin{array}{l}\text { No } \\
\text { No } \\
\text { No }\end{array}$ & $\begin{array}{l}4-6 \\
8 \\
8\end{array}$ & $\begin{array}{l}\text { Up to } 12 \\
\text { NA } \\
\text { NA }\end{array}$ \\
\hline 14 & Light $x$ ray room & $6 \times 3$ & NA & & No & 8 & NA \\
\hline
\end{tabular}

The data given in this table do not just relate to the day of measurement but indicate typical operating conditions. Where a range is quoted this is because there are different requirements on different days. NA = not applicable.

collected when workers were directly handling CIDEX over periods of four to 26 minutes. These were considered to represent worst case exposure situations.

Samples were also collected at static locations at roughly head height positions over open tanks and above automated cleaning units. Sampling periods for the static samplers ranged from five to 38 minutes.

\section{Results}

Table 2 summarises the results from the personal monitoring, subdivided according to the specific activity undertaken. Sampling periods ranged from four to 26 minutes. Exposure concentrations of 0.003 to $0.17 \mathrm{mg} \mathrm{m}^{-3}$ were measured. All were within the 10 minute TWA occupational exposure standard of $0.7 \mathrm{mg} \mathrm{m}^{-3}$. The highest exposures during endoscope cleaning activities were recorded for manual operations such as the activation and changeover of glutaraldehyde solutions. These activities typically occupy one person for a period of about five to 10 minutes at the start and end of the week. The highest exposure during the survey $(0 \cdot 17$ $\mathrm{mg} \mathrm{m}^{-3}$ ) was found during the cleaning of suction bottles with CIDEX.

The lowest exposures were recorded for those working with $x$ ray processing chemicals $(0.003$ to $0.006 \mathrm{mg} \mathrm{m}^{-3}$ ). Workers in these areas were generally concerned with the health risks associated with glutaraldehyde to the exclusion of those of other components of the processing fluids. Some of these, for example acetic acid and diethylene glycol, are present in greater amounts than glutaraldehyde and are also more volatile. Overall they are likely to pre- sent a greater inhalation exposure risk than glutaraldehyde.

Table 3 gives the results from the static monitoring. The concentrations ranged from 0.002 to $0.23 \mathrm{mg} \mathrm{m}^{-3}$, with the highest concentrations recorded above open tanks of CIDEX and the lowest above the EW10 automatic unit.

\section{Discussion}

With the exception of 12 samples collected in operating theatres the locations monitored were not provided with forced general or local mechanical ventilation; nor were there openable windows in the immediate vicinity. All monitoring was carried out in the summer. In all the locations monitored the activities undertaken were reported to be typical of those normally carried out.

During the course of the study no one was in direct contact with glutaraldehyde for a full working shift. The typical pattern of exposure was contact for a four to five minute period, repeated once every 30 minutes or so throughout the shift when endoscopes were put into or removed from cleaning units.

One advantage of the automatic cleaning units would seem to be the reduction of the risk of skin contact with glutaraldehyde solution. The static monitoring results (table 3 ) indicate that a reduction in vapour concentrations may also be obtained, in particular with the EW10 automatic cleaning unit.

For the activities undertaken it was evident that skin contact could occur either because gloves were not worn or from splashes on to exposed skin such as forearms and faces. Two people encountered 
Table 2 Summary of results of personal exposure measurement

\begin{tabular}{|c|c|c|c|c|c|c|}
\hline \multirow[b]{2}{*}{ Location } & \multirow[b]{2}{*}{ Description of activity } & \multirow{2}{*}{$\begin{array}{l}\text { No of } \\
\text { samples }\end{array}$} & \multirow{2}{*}{$\begin{array}{l}\text { Duration of } \\
\text { sampling period } \\
(\text { min) }\end{array}$} & \multicolumn{3}{|c|}{ Airborne glutaraldehdye concentration } \\
\hline & & & & Range (mg $\left.m^{-3}\right)$ & Mean $\left(m g m^{-3}\right)$ & Median $\left(m g m^{-3}\right)$ \\
\hline 1 & $\begin{array}{l}\text { Activating CIDEX, filling } \\
\text { and emptying tanks }\end{array}$ & 3 & $5-26$ & $0.014-0.13$ & 0.066 & 0.055 \\
\hline 2 & $\begin{array}{l}\text { Endoscope cleaning with } \\
\text { KEYMED AUTO-2 units }\end{array}$ & 12 & $4-22$ & $0 \cdot 003-0 \cdot 11$ & 0.032 & 0.022 \\
\hline 3 & $\begin{array}{l}\text { Endoscope cleaning with } \\
\text { bowls or troughs of CIDEX }\end{array}$ & 8 & $5-17$ & $0.005-0.017$ & 0.021 & 0.014 \\
\hline 4 & $\begin{array}{l}\text { Cleaning instruments in } \\
\text { bowls of CIDEX in theatre }\end{array}$ & 6 & $15-21$ & $0.011-0.025$ & $0 \cdot 013$ & 0.014 \\
\hline 5 & $\begin{array}{l}\text { Cleaning suction bottles with } \\
\text { CIDEX }\end{array}$ & 1 & 15 & & $0 \cdot 17$ & $0 \cdot 17$ \\
\hline 6 & $\begin{array}{l}\text { Cleaning equipment in } \\
\text { haemophilia centre }\end{array}$ & 2 & 15 & $0.005-0.014$ & $0 \cdot 010$ & $0 \cdot 010$ \\
\hline 7 & Work in $x$ ray development & 7 & $14-19$ & $0.003-0.006$ & 0.005 & 0.005 \\
\hline
\end{tabular}

during the survey commented spontaneously that they suffered from rhinitis, which they attributed to exposure to glutaraldehyde. This implies that some persons may experience adverse effects at concentrations below the current occupational exposure standard and indicates that a review of this limit may be appropriate.

Glutaraldehyde solution was used in some locations for sterilising instruments that could have been treated by standard heat sterilisation. The reasons given for this included the fact that insufficient equipment was available to cover the requirements of particular clinics. We were also told during the survey that glutaraldehyde had been used to clean down bench surfaces in a haematology laboratory to "kill" HIV although this practice had been discontinued. In one hospital suction bottles used to receive excretions from patients contained, and were cleaned with glutaraldehyde. There were reports from hospital staff that it is still used in certain areas to wash walls and for the cleaning of bed pans. A dentist told us that he and other colleagues on occasion use glutaraldehyde to sterilise instruments, which would seem to be a legitimate use, and to wipe surfaces, which should not be necessary. Non-essential uses should be reviewed and alternative procedures introduced.

At the time the survey was originally planned it was considered that under most circumstances there would be inadequate control of exposure to glutaraldehyde by inhalation. Our data suggest that as long as non-essential uses of glutaraldehyde are prohibited, and that it is handled appropriately, the current occupational exposure standard should not be exceeded. (Recommendations for safe handling are given in the appendix.) Nevertheless, there is some suggestion that the current occupational exposure standard may be too high, ${ }^{12}$ and medical surveillance of staff with significant exposure seems prudent.

We thank the Department of Health for the grant that enabled this work to be undertaken

\section{Appendix}

RECOMMENDATIONS FOR THE SAFE USE OF GLUTARALDEHYDE

(1) Glutaraldehyde should only be used where other sterilising techniques are inappropriate.

(2) Good occupational hygiene principles and handling practices should be adopted to reduce exposures to glutaraldehyde to as low a level as is reasonably practicable. In circumstances in which open baths of glutaraldehyde are used, or there are manual transfer operations, there is a requirement for adequate ventilation at the point of emission, even when the equipment is automated. This requirement may necessitate the use of well designed local extract ventilation systems.

(3) Staff should be given appropriate training in

Table 3 Summary of static monitoring results

\begin{tabular}{|c|c|c|c|c|c|c|}
\hline \multirow[b]{2}{*}{ Location } & \multirow[b]{2}{*}{ Description of activity } & \multirow{2}{*}{$\begin{array}{l}\text { No of } \\
\text { samples }\end{array}$} & \multirow{2}{*}{$\begin{array}{l}\text { Duration of } \\
\text { sampling period } \\
\text { (min) }\end{array}$} & \multicolumn{3}{|c|}{ Airborne glutaraldehdye concentration } \\
\hline & & & & Range ( $m g m^{-3}$ ) & $\operatorname{Mean}\left(m g m^{-3}\right)$ & Median ( $\left.m g m^{-3}\right)$ \\
\hline 1 & $\begin{array}{l}\text { Head height above EW } 10 \\
\text { automatic cleaning units }\end{array}$ & 5 & $16-38$ & $0.002-0.024$ & 0.008 & 0.004 \\
\hline 2 & $\begin{array}{l}\text { Head height above KEYMED } \\
\text { AUTODISINFECTOR } 2 \\
\text { units }\end{array}$ & 10 & $14-34$ & $0.011-0.21$ & 0.053 & 0.031 \\
\hline 3 & Head height above open tanks & 8 & $5-16$ & $0.014-0.23$ & 0.093 & 0.083 \\
\hline
\end{tabular}


the techniques that should be adopted to achieve adequate control of exposure.

(4) Skin contact should be minimised by personal protection. The particular items required will depend on the potential for exposure. These can be selected as appropriate from: nitrile gloves, surgical gloves; goggles, visor; plastic apron (to prevent clothing from contamination). For example, if there is known contact rather than the potential for splashing with glutaraldehyde solution, then nitrile and not surgical gloves should be worn.

(5) Damaged gloves should be replaced immediately. Gloves should be rinsed with water before removal.

(6) Where there is a risk of glutaraldehyde solution being splashed on to the forearms gloves must be of a sufficient length to provide adequate protection. Any splashes on to the skin should be washed off immediately.

(7) Any spills on floors and benches must be cleaned up immediately. Cloths or paper wipes used for this purpose should be disposed of in a sealed container or allowed to evaporate in a well ventilated area.

(8) All receptacles containing, or that have contained, glutaraldehyde solution should be kept covered when not in use. It may be appropriate to use receptacles with pedal operated hinged top lids. In this way lids cannot be left off containers inadvertently and can be readily manipulated by means of a foot pedal.

(9) Only respiratory protection known to provide adequate protection against the concentrations of glutaraldehyde encountered should be used. Surgical masks do not provide such protection. Systems should be established for the correct selection, issue, and maintenance of all respiratory protection and training should be given in its use.

1 The control of substances hazardous to health regulations 1988 approved codes of practice. London: HMSO, 1988.

2 Corrado OJ, Osman J Davies RJ. Asthma and rhinitis after exposure to glutaraldehyde in endoscopy units. Human Toxicology 1986;5:325-7.

3 Norback D. Skin and respiratory symptoms from exposure to alkaline glutaraldehyde in medical services. Scand $\mathcal{f}$ Work Environ Health 1988;14:366-71.

4 Jachuk SJ, Bound CL, Steel J, Blain PE. Occupational hazard in hospital staff exposed to $2 \%$ glutaraldehyde in an endoscopy unit. F Soc Occup Med 1989;39:69-71.

5 Wiggins P, McCurdy SA, Zeidenbery W. Epistaxis due to glutaraldehyde exposure. F Occup Med 1989;31:854-6.

6 Binding N, Wittig K. Exposure to formaldehyde and glutaraldehyde in operating theatres. Int Arch Occup Environ Health 1990;62:233-8.

7 American Conference of Governmental Industrial Hygienists. Documentation of threshold limit values. 4 th ed. Cincinnati: ACGIH; 1980.

8 Hellmar TM, Small FH. Characterisation of the odour properties of 101 petrochemicals using sensory methods. fournal of the Air Pollution Control Association 1974;24:979-82.

9 Health and Safety Executive. Guidance note EH40/92 occupational exposure limits 1992. London: HMSO, 1992.

10 British Society of Gastroenterology. Cleaning and disinfection of equipment for gastrointestinal flexible endoscopy: interim recommendations of a working party of the British Society of Gastroenterology. Gut 1988;29:1134-51.

11 Occupational Safety and Health Administration. Method number 64, glutaraldehyde. OSHA analytical laboratory 1987. Salt Lake City, Utah: Organic Methods Evaluation Branch, OSHA Analytical Laboratory, 1987.

12 Burge PS. Occupational risks of glutaraldehyde. BMF 1989; 299:342.

Accepted 7 September 1992 